provide strengthened undergraduate courses integrated around more enduring scientific foundations. The Center hopes to arrange courses, among others, in modern atomic and nuclcar physics, feedback control, automation, information theory and advanced theories of communications, modern computer technology, solid-state physics, plasma physics, modern approaches to electromagnetic theory, probability theory, relativity theory and extraterrestrial science.

\section{Fleming Memorial Fund Grants}

The Trustees of the Fleming Memorial Fund for Medical Research have announced four grants to assist basic medical research. A grant of $£ 75,000$ has boon made to St. Mary's Hospital Medical School-where Sir Alexander Fleming worked--to help the foundation in the WrightFleming Institute of a Department of Virology with a professorial head. This is the Fund's largest grant so far. A second grant has beon made to St. Mary's Hospital Medical School of $£ 4,200$ to assist a two-ycar research project investigating the mechanism of intracellular killing of bacteria and the phagocytic function in man, under the direction of Dr. A. A. Glynn. University Colloge, London, and University College Hospital Medical School share a Fund grant of $£ 16,000$ to extend interdepartmental research in human genetics, and initiate new projects in this field under the direction of Profs. L. S. Penrose and M. L. Rosenheim. The technical facilities of the Galton Laboratory and Medical Unit will be used in the genetical investigation of clinical material available in the Medical Unit and other Departments of University College Hospital. Additionally, the Fund has made a grant to University College Hospital Medical School of $£ 8,000$ for a general study of influenza virus hæmagglutination inhibition reaction under the direction of Prof. G. Belyavin.

\section{Industrial Training in Britain}

A FULu report of the conference arrangement to discuss the Government proposals for industrial training on January 15 has now been published by the British Association for Commercial and Industrial Education under the title Industrial Training: Whose Responsibility? Cmnd. 1892: The Next Step (Pp. 78. London: British Association for Commercial and Industrial Education, 1963. 12s. 6d.; 8s. 6d. members. See also Nature, 198, 1 ; 1963). It includes the speeches of the Minister of Labour, Sir John Hare, Lady Williams, Mr. Frank Cousins, Dr. D. E. Woodbine Parish and Major-General C. Lloyd, who summed up, as well as the replies of the speakers to questions raised in the discussion. Inasmuch as the text of the White Paper itself is appended, the pamphlet is a most useful guide to the present position, and various points are elucidated which aro not clear in the White Paper itself. Lady Williams thought that any test at the end of apprenticeship should be mainly practical, and that the proposed Boards should recognize responsibility for training other people as well as the highly skilled worker. She stressed the importance of adaptability, but questioned whether tho choice for responsibility for the scheme lay between the Minister of Labour and the Minister of Education. Mr. Cousins stressed the need for flexible training and the implications for a shorter training period. He thought that the White Paper underestimated the magnitude of the task. There was some discussion both of the constitution of the Boards and of their finance, and the Association, which has alrcady set up a Standing Committee to keep developments under review, has forwarded a copy of the Conference report to the Minister of Labour, together with a memorandum directing attention to some obstacles likely to be encountered and offering constructive suggestions as to how these difficulties might be overcome. These include suggestions rogarding topies on which further information is required, the functions of a central coordinating body, the role of inspectors, the supply of training officers, which is likely to be a main obstacle, finance, and craft apprenticeship.

\section{The International Council of Scientific Unions}

The Year Book of the International Council of Scientific Unions, 1963, contains the usual compendium of information regarding the membership of the Council and of the International Scientific Unions and their numerous Commissions, as woll as the Statutes and Rules of Procedure, etc. (Pp. 140. Rome: International Council of Scientific Unions, 2 Via Sebenico, 1963). Its earlier publication means that the customary calendar of meetings for the year has considerable practical value this year.

\section{Man in His World}

IN his pamphlet, Man in His World, Mr. K. W. Monsarrat amplifies conclusions reached in his book On Human Thinking as to man's innate ideas regarding the nature of an organization of his 'self' and 'the world' (Pp. 13. Liverpool: K. W. Monsarrat, 29 Aigburth Drive, 1963). This he doos in order to develop the argument that since the stability of each nation and degree of welfare of its members depend first on its own internal order, and secondly on its relations with other national groups, every member of a nation shares responsibility for its equilibrium and each nation must show practical friendship in its dealings with others. Deriving his argument from the conception of man as a dynamic system in a world of dynamic systems, he urges that the soundest international policy is to put the remedying of want and discase in the forefront without regard to the nationality of the followers. This he regards as the most hopeful alternative to nuclear armaments.

\section{John White: Artist and Naturalist}

Among the small group of illustrators of plants and animals living in England towards the end of the sixteenth century, the outstanding figure was John White. Almost all his drawings were connected with exploration. $\mathrm{He}$ took part in no less than six expeditions to the Americas, the first, under Martin Frobisher, in 1577, and others afterwards under Walter Raleigh, acting as a cartographer and artist. Among his drawings of plants he was probably the first to figure the banana, but he was at his best in representing animals like the iguana, trigger-fish, roseate flamingo and an exquisite swallow-tail butterfly, producing pictures in which he combined acuity of observation with high æesthetic sensibility. Many of his paintings were lost when disaster befell the settlement on Roanoke Island, while through the vicissitudes of time some of the remainder can no longer be traced. His works were frequently copied by other artists, so that in an indirect manner he had some representation in Gerard's Herball and Linnæus's Systema Naturae. By various routes, a fair number of his original drawings, along with a collection of copies, have found their way into the British Museum (Natural History). Recently the life and work of John White have been reviewed by D. B. Quinn and P. H. Hulton ("John White and the English Naturalists", History Today, 8, 310; 1963). The article is illus trated with some fine examples of White's artistic skill. From it we learn that, in collaboration with the Museum, the University of North Carolina Press is about to publish a book by the same authors, in which all White's extant original paintings will appear in colour and the copies in black and white.

\section{Conference of Commonwealth Meteorologists}

THE Conforoneo of Commonwealth Meteorologists was in session this year during May 7-10 at the Headquarters Building of the Meteorological Office, Bracknell, Berkshire. Discussions were held on the development of Commonwealth meteorological services during the next five years or so, including exchange training schemes, new instrumentation, communications problems and the 